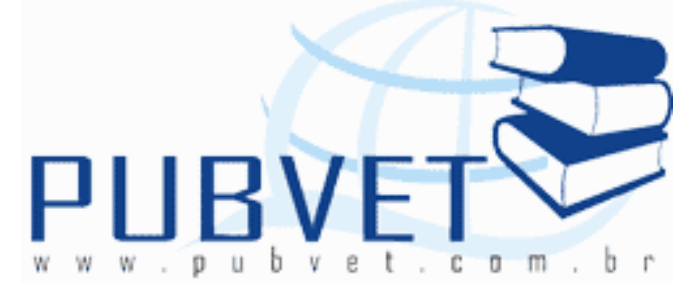

PUBVET, Publicações em Medicina Veterinária e Zootecnia.

\title{
Criação de Matrinxã em cativeiro
}

\section{Ewertton Souza Gadelha ${ }^{1}$, Jamile da Costa Araújo ${ }^{2}$}

${ }^{1}$ Graduando do curso de Engenharia de Pesca da Universidade Federal Rural da Amazônia (UFRA)

${ }^{2}$ Doutoranda do curso de Zootecnia da Universidade Federal de Lavras (UFLA). E-mail: jamilejca@yahoo.com.br

\section{Resumo}

O matrinxã (Brycon cephalus, B. amazonicus e B. orthotaenia) é um teleósteo endêmico da região amazônica, muito apreciado pelo sabor de sua carne e qualidade proteica, despertando interesse de pescadores de outras regiões brasileiras. Devido sua grande procura no mercado brasileiro sua criação em cativeiro mostrou-se como uma alternativa para minimizar a caça predatória. Em cativeiro apresenta baixo nível de estresse, além de ser capaz de digerir quase todo tipo de alimento, diante disso, pesquisadores visam melhorar a sua adaptabilidade em cativeiro, gerando várias pesquisas, nas diferentes áreas zootécnicas, como nutrição, reprodução e comportamento. Atualmente, procura-se minimizar a taxa de canibalismo presente nessa espécie, para tanto, é indissociável o conhecimento de sua morfologia; biologia e comportamento quando em vida livre. Ciente dessas informações é possível oferecer embasamento para criações de tecnologias eficazes e sustentáveis. Portanto, objetivou-se reunir e analisar informações presentes na literatura, 
GADELHA, E.S. e ARAÚJO, J.C. Criação de Matrinxã em cativeiro. PUBVET, Londrina, V. 7, N. 5, Ed. 228, Art. 1507, Março, 2013.

sobre a morfologia e a biologia, além das técnicas empregadas na criação em cativeiro do matrinxã. Com isso, foi observado que o matrinxã possui um curto período de vida, o que propicia um crescimento rápido, além de possuir fecundidade elevada, entretanto, ainda são escassos estudos que contribuam para melhoria do canibalismo na larvicultura, apesar de muitos experimentos já terem sido executados, porém, ou não conseguem êxito, ou a taxa de sobrevivência das larvas não condiz com os gastos com alimentação adequada. Nesse contexto, a aplicação de hormônios se mostrou uma alternativa efetiva na diminuição desse canibalismo, contudo seus efeitos na sanidade humana devem ser avaliados.

Palavras-chave: Piscicultura, Manejo, Biologia, Brycon, Amazônia.

\section{Matrinxã captive breeding}

\section{ABSTRACT}

Matrinxã (Brycon cephalus, B. amazonicus and B. orthotaenia) is a teleost endemic to the Amazon region, much appreciated by the flavor of their meat and protein quality, arousing the interest of fishermen from other Brazilian regions. Due to their high demand in the Brazilian market showed its captive breeding as an alternative to minimize poaching. In captivity a low stress level, and be able to digest almost any type of food, before this, researchers are aiming to improve their adaptability in captivity, creating multiple searches in different areas of breeding: nutrition, reproduction and behavior. Currently, we seek to minimize this rate of cannibalism in this species, for it is inseparable from the knowledge of their morphology, biology and behavior when in the wild. Knowing this information can provide basis for creation of effective and sustainable technologies. Therefore, the objective was to gather and analyze information in the literature on the morphology and biology, in addition to the techniques employed in the captive breeding of matrinxã. Thus, it was observed that matrinxã has a short life span, which allows for rapid growth and also has high fertility, however, are still few studies that contribute to 
GADELHA, E.S. e ARAÚJO, J.C. Criação de Matrinxã em cativeiro. PUBVET, Londrina, V. 7, N. 5, Ed. 228, Art. 1507, Março, 2013.

cannibalism in hatchery improvements, although many experiments have already been run, however, succeed or fail, or the survival rate of larvae does not match the spending adequate food. In this context, the use of hormones has proved an effective alternative in the reduction of cannibalism, yet its effects on human health should be evaluated.

Keywords: Fish farming, Management, Biology, Brycon, Amazon.

\section{INTRODUÇÃO}

A Amazônia é uma região de grande diversidade aquática, por conta disso, a pesca e a aquicultura estão extremamente vinculadas à região, além de despertar interesse de pesquisadores. Dentre as espécies aquáticas amazônicas, que atualmente são exploradas, destaca-se 0 matrinxã, pertencente à sub-família Bryconinae, que compreende um grupo de 43 espécies e mostra uma ampla distribuição na América do Sul e Central, com representantes nas principais bacias hidrográficas brasileiras. Este gênero se destaca dentro da ordem dos Characiformes por apresentar algumas espécies com elevado potencial zootécnico (ZANIBONI FILHO et al., 2006). O matrinxã apresenta muitas espécies, contudo, os mais estudados são as espécies Brycon amazonicus (Spix e Agassiz, 1829) e Brycon cephalus (Günther, 1869). Há equívocos sobre a diferenciação destas espécies, pelo fato das mesmas serem bastante parecidas, Lima (2003) constatou que a espécie Brycon cephalus, que ocorre na Amazônia brasileira, amplamente criada no Brasil é, na verdade, $B$. amazonicus, e que $B$. cephalus está restrita ao alto rio Amazonas no Peru e Bolívia.

O matrinxã é um peixe de grande importância para a Amazônia Ocidental, onde este ocupa um importante volume de desembarque e comercialização, principalmente em Manaus, AM, Brasil (MERONA E BITENCOURT, 1988), somente em 2007 o matrinxã contribuiu para o crescimento do pescado comercializado com 14,4\% (IBAMA, 2007), devido a crescente comercialização, os pesqueiros da região sudeste de São Paulo 
GADELHA, E.S. e ARAÚJO, J.C. Criação de Matrinxã em cativeiro. PUBVET, Londrina, V. 7, N. 5, Ed. 228, Art. 1507, Março, 2013.

despertaram interesse em caçá-lo (SCORVO FILHO, 1998). A pesca artesanal é um dos grandes responsáveis por este crescimento, onde, as mesmas utilizam rede de espera tipo malhadeira e linhada para capturar o animal (MINISTÉRIO DA INTEGRAÇÃO NACIONAL, 2006). Sendo o mesmo capturado no rio Amazonas, rio Madeira, rio Orinoco, rio Negro, rio São Francisco e rio Tocantins, em algumas áreas do Peru e da Bolívia.

Este peixe apresenta importância econômica para a piscicultura na Colômbia e principalmente na região norte do Brasil, sendo o terceiro peixe mais consumido, com produção na aquicultura nacional em 2010 de 2981,9 toneladas (LIMA, 2005; VALBUENA et al., 2006; OSTRENSKY et al., 2008; MINISTÉRIO DA PESCA E AQUICULTURA, 2010). Tal espécimes despertam interesse de piscicultores devido ao sabor da carne, boa conversão alimentar, adaptação a ração artificial, fácil propagação e rápido crescimento na fase larval e alevinagem, o que permite uma comercialização mais rápida e, portanto, melhor aproveitamento dos viveiros de criação (CASTAGNOLLI, 1992; LEONARDO, 2005; TAVARES-DIAS et al., 1999; ZANIBONI FILHO et al., 2006; SANTOS FILHO e BATISTA, 2009; VALBUENA et al., 2006).

É um peixe de grande interesse na comunidade científica, devido ser amplamente capturado por frotas pesqueiras, e sua biologia permitir que seja criado em cativeiro, possuindo diversos estudos na área de crescimento, desova induzida e redução do canibalismo. Por tanto, objetivou-se reunir e analisar informações presentes na literatura, sobre a biologia e as técnicas empregadas na criação em cativeiro do matrinxã, abordando três espécies ( $B$. cephalus, B. amazonicus e B. orthotaenia).

\section{SISTEMA DE CULTIVO}

O matrinxã pode ser criado satisfatoriamente, tanto em criação semiintensiva quanto na intensiva (ARBELÁEZ-ROJAS et al., 2002), em monocultivo ou preferencialmente policultivo (ANELLI JUNIOR, 2010). Brandão et al. (2005) afirmam que sua criação em tanques-rede apresentou bons resultados. 
GADELHA, E.S. e ARAÚJO, J.C. Criação de Matrinxã em cativeiro. PUBVET, Londrina, V. 7, N. 5, Ed. 228, Art. 1507, Março, 2013.

Contudo, é preciso ter cuidado com a densidade de estocagem em cativeiro, pois a elevada densidade é um fator desencadeante do estresse, sendo este um dos maiores entraves na piscicultura, pois quanto maior for à vulnerabilidade do animal em atingir este estágio menor é a possibilidade deste ser criado em cativeiro, já que o estresse afeta a reprodução e a engorda. Hoshiba et al. (2009) relatam que o matrinxã é um peixe bastante resistente ao manejo, ou seja, não é facilmente afetado pelo estresse, fato este, que impulsiona este teleósteo a ser uma das espécies nativas mais promissora na aquicultura. Segundo Marques et al. (2004) juvenis de matrinxã apresentam melhor desempenho em comprimento total e peso, em densidade de 20 peixes $/ \mathrm{m}^{-3}$, enquanto, Brandão et al. (2005) relatam que juvenis com peso de 0,56 $\pm 0,20 \mathrm{~g}$ apresenta melhor densidade de estocagem com 500 peixes por $\mathrm{m}^{-3}$ em tanques de $200 \mathrm{~L}$, todavia, Arbeláez-Rojas e Moraes (2009) afirmam que a criação de juvenis de matrinxã (com peso de $18,4 \pm 0,1 \mathrm{~g}$ ) sob condições de exercício moderado e em densidades próximas a 176 peixes $\mathrm{m}^{-3}$, é a mais indicada, pois estes observaram melhores respostas de crescimento e desempenho, além de mudanças benéficas na composição corporal. Essas mudanças resultaram em melhor condicionamento físico, possibilitando, assim, maior tolerância a altas densidades de criação. Totolero et al. (2010) idealizaram gaiolas flutuantes, como meio de cultivar matrinxã de forma sustentável, as gaiolas eram construídas de paxuíba (Iriartea exorrhiza), bambu (Guadua angustifólia), taboca (Guadua superba) e cipó titica (Heteropsis jemanii) que eram sustentadas na superfície da água por um sistema de flutuação constituído por assacú (Hura crepitans) e jacareuba, (Calophyllum brasiliensis). Neste sistema a melhor densidade de criação é 150 e/ou 200 peixes $/ \mathrm{m}^{3}$. Gomes et al. (2000) relatam que alevinos que são destinados a venda, as larvas devem ser cultivadas em uma densidade de 120 larvas $/ \mathrm{m}^{2}$, todavia, se o intuito for cultivar os alevinos, as larvas devem ser criadas em uma densidade de 30 larvas $/ \mathrm{m}^{2}$, pois neste sistema de densidade o tamanho uniforme é maior, que na densidade anteriormente citada, contudo a heterogeneidade e o tamanho são menores. 
GADELHA, E.S. e ARAÚJO, J.C. Criação de Matrinxã em cativeiro. PUBVET, Londrina, V. 7, N. 5, Ed. 228, Art. 1507, Março, 2013.

\section{HABITAT}

O Matrinxã habita ambientes de água doce tropical, sendo uma espécie bentônica (FAUSTINO et al., 2010). Larvas e juvenis são encontrados em lagos e na floresta alagada (HOSHIBA, 2007), quando na fase larval entre as macrófitas aquáticas (LEITE, 2004). Costumam ficar na coluna d'água, atrás de obstáculos como galhos, pedras e vegetação marginal durante a seca (ZEINAD, 2011). Quando adulto, vive em ambientes de correnteza, onde alojase preferencialmente nas águas rápidas e frias das corredeiras dos igarapés (GOULDING, 1979; ZANIBONI FILHO, 1985; FERREIRA et al., 1998; NEUMANN, 2008).

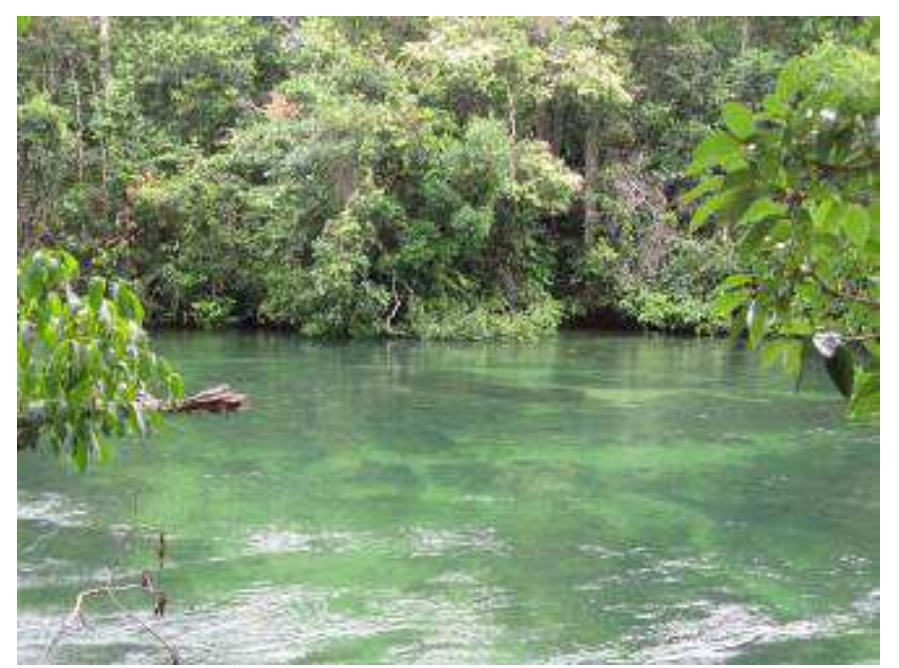

Figura 1. Amostra de habitat de Matrinxã.

Fonte: http://www.habtec.com.br/experiencia/clientes/santa-gisele/pch-bacuri/

\section{HÁBITO E COMPORTAMENTO ALIMENTAR NATURAL}

De hábito alimentar onívoro, o matrinxã possui tendência ao herbivorismo, com amplo espectro alimentar na fase adulta, sendo dependente de alimentos alóctones durante a época da cheia e tendo disponível na época da seca, em sua maioria, alimentos de origem autóctone (ZANIBONI FILHO, 2006; SILVA, 2007), o que dificulta a caracterização de sua alimentação. Este teleósteo é bastante voraz e agressivo na hora do arraçoamento, se alimentando de qualquer item que caia na água. Dois fatores podem contribuir 
GADELHA, E.S. e ARAÚJO, J.C. Criação de Matrinxã em cativeiro. PUBVET, Londrina, V. 7, N. 5, Ed. 228, Art. 1507, Março, 2013.

para isso: conseguir energia para a reprodução; e manter as reservas para o período de seca, pois nesta época diminui a oferta de alimento (HONCZARYK, 1999; SILVA, 2007). Na fase larval o espécime se alimenta de zooplâncton e, principalmente, de larvas de outras espécies de peixe (LEITE E ARAÚJO-LIMA, 2002). Leite (2004) afirma que a preferência alimentar deste teleósteo na fase juvenil é por restos vegetais e secundariamente por microcrustaceos (Figura 2), enquanto que Silva (2007) afirma que sua fonte secundária de alimento são insetos. De acordo com Pizango - Paima et al. (2001) no período de cheia predominam em sua alimentação as sementes seguidas por restos vegetais, já na seca de restos de peixe com valores baixos de insetos, o que reforça a idéia anterior de que a sua alimentação é influenciada pelos períodos de seca e de cheia dos rios. Quando adulto possui baixa capacidade de utilizar fito e zooplâncton na sua alimentação, pois seus rastros branquiais são mais grossos, mais separados entre si e em menor número (FIM, 1995).

A
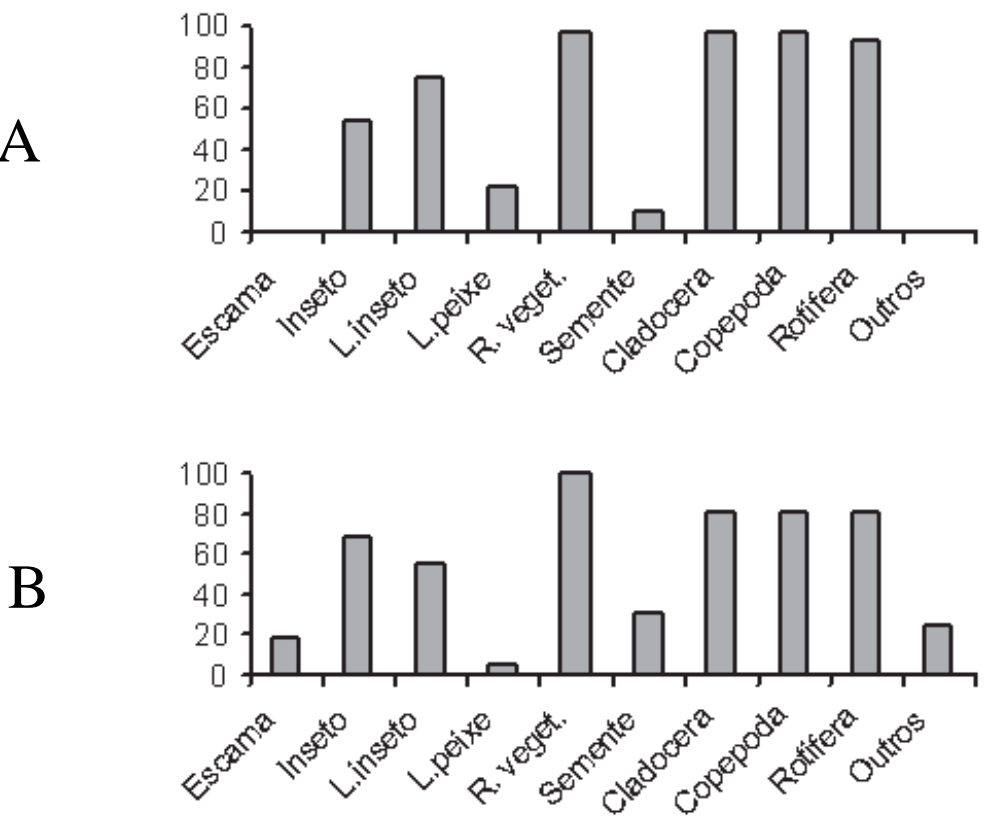

Figura 2. Gráficos da Freqüência de Ocorrência (\%) dos itens alimentares encontrados no estômago de Brycon amazonicus, de 15 a $25 \mathrm{~mm}$ (A) e 25 a $50 \mathrm{~mm}$ (B) de Comprimento Padrão capturados em áreas inundadas da Ilha de Marchantaria nos meses de janeiro, fevereiro e dezembro de 1994.

Fonte: Leite (2004) 
GADELHA, E.S. e ARAÚJO, J.C. Criação de Matrinxã em cativeiro. PUBVET, Londrina, V. 7, N. 5, Ed. 228, Art. 1507, Março, 2013.

\section{MORFOLOGIA}

O matrinxã possui o corpo alongado, pouco alto e levemente comprimido, com região ventral arredondada, possui uma pigmentação ligeiramente mais escura na parte dorsal, a coloração do corpo é prateada, com as nadadeiras alaranjadas, sendo a nadadeira caudal cinza escura e apresenta uma nadadeira adiposa (Figura 3). Apresenta uma mancha arredondada escura na região umeral (ZANIBONI FILHO, 2006; SOARES et al., 2008). As escamas são do tipo ciclóide, a boca é terminal, com dentes dispostos em série tríplice, espessos e multicuspidados, nadadeira caudal bifurcada, como citado anteriormente os rastros branquiais são mais grossos, mais separados entre si e em menor número (SILVA, 2007; LEITE, 2004; BRITSKI et al., 1999). Como todo peixe ósseo, este apresenta bexiga natatória para auxiliá-lo na natação, e quando larva, a cabeça é voltada para baixo, aderida a região anterior do saco vitelino, com o corpo em postura distendida, ausência total de nadadeiras e sistema incompleto (FREITAS, 2010). O fígado deste teleósteo acumula gordura proveniente da gordura evisceral, depositada como reserva de energia não utilizada na migração da reprodução (ZANUZZO, 2010). O macho quando pronto para copulação seu testículo tem coloração esbranquiçada (Figura 4), tais órgãos são estruturas pares, alongadas, sendo formadas por vários túbulos seminíferos, estando localizados na porção dorsal da cavidade abdominal. A gônada feminina apresenta forma alongada, quando imatura coloração rósea, e quando matura forma globulosa (Figura 4), para copulação a coloração muda para verde-azul anil, com a parte ventral bastante vascularizada, situando-se dorso-lateralmente a cavidade abdominal (ZANIBONI FILHO, 1985; FREITAS, 2010). Os ovos são esféricos, transparentes, semidensos e de coloração esverdeada, já os espermatozóides são do tipo "aquasperm", apresentando uma pequena cabeça arredondada e sem vesícula acrossomal (NEUMANN, 2008). O tubo digestório pode ser dividido em dois segmentos: esôfago (intestino anterior) e intestino médio, sendo o intestino médio subdividido em bolsa intestinal na região proximal (figura 5), tubo retilíneo com pregas transversais na região média, e intestino 
GADELHA, E.S. e ARAÚJO, J.C. Criação de Matrinxã em cativeiro. PUBVET, Londrina, V. 7, N. 5, Ed. 228, Art. 1507, Março, 2013.

afunilado na região distal, com pregas paralelas longitudinais no segmento retal, além da presença de cecos pilóricos (FREITAS, 2010), o estômago possui formato de U (NEUMANN, 2008).

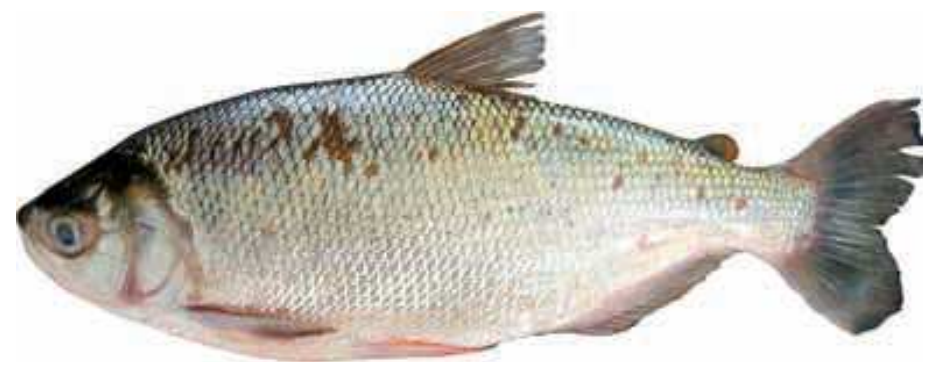

Figura 3. Brycon amazonicus.

Fonte: Soares et al. (2008) 
GADELHA, E.S. e ARAÚJO, J.C. Criação de Matrinxã em cativeiro. PUBVET, Londrina, V. 7, N. 5, Ed. 228, Art. 1507, Março, 2013.

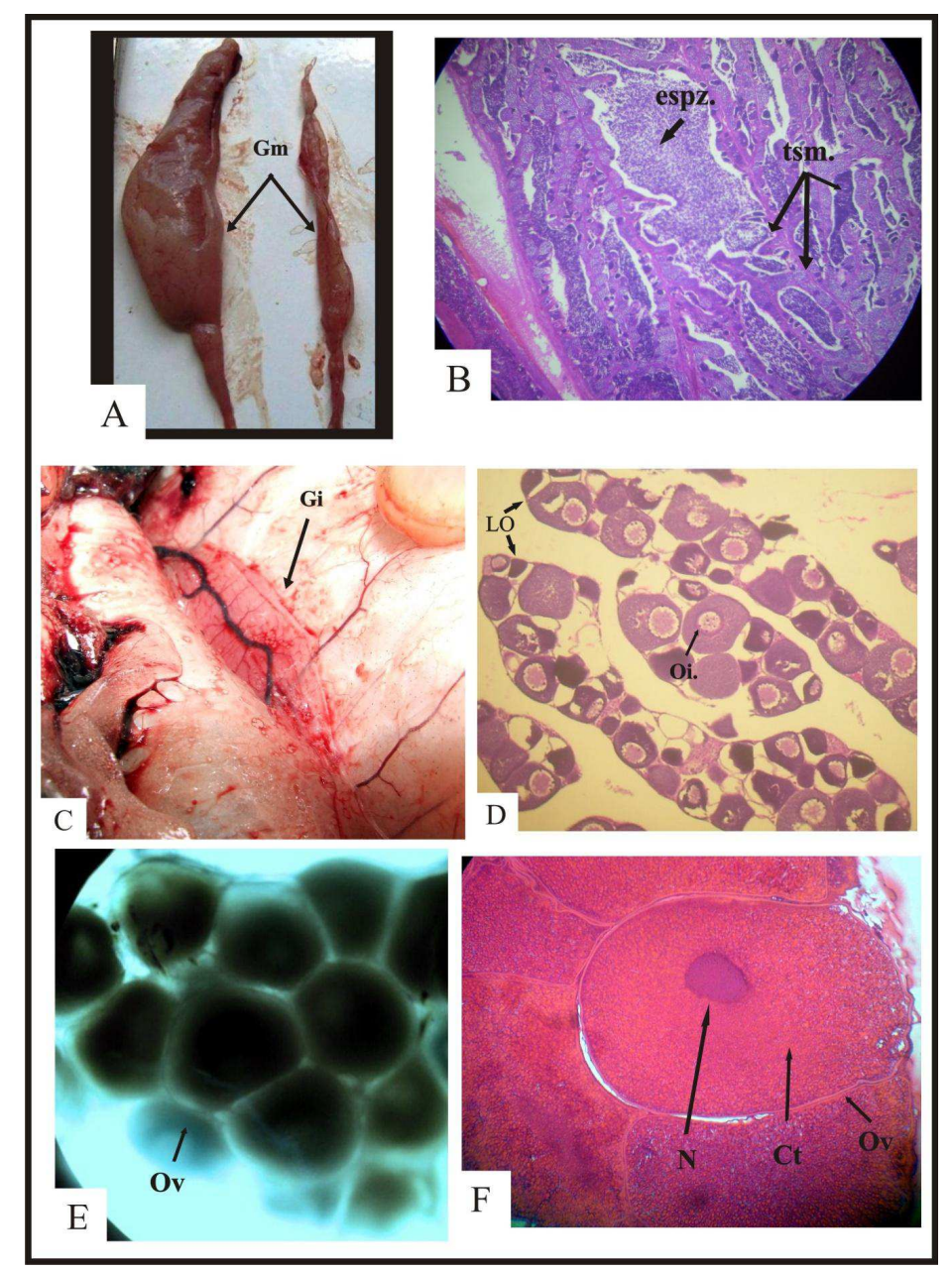

Figura 4. Cortes transversais de gônadas de $B$. amazonicus mostrando desenvolvimento gonadal da espécie. A - Observação macroscópica de gônadas de machos maduros $(\mathrm{Gm})$; B - Corte de testículo da matrinxã em maturação avançada com um ano de idade. Espermatozóides (espz); Túbulos seminíferos (tms). C Observação macroscópica de gônadas imaturas (Gi). D - Corte de ovário imaturo ou virgem (primeiro ano de vida) mostrando oócitos do estoque de reserva. Lamelas ovígeras (LO); Oócitos imaturos (Oi). E - Ovócito maduro de animal no segundo ano de vida: Ovócito maduro (Ov). F - Ovócito maduro no segundo ano de vida: Ovócito maduro (Ov); Citoplasma (Ct); Núcleo (N).

Fonte: Freitas (2010). 
GADELHA, E.S. e ARAÚJO, J.C. Criação de Matrinxã em cativeiro. PUBVET, Londrina, V. 7, N. 5, Ed. 228, Art. 1507, Março, 2013.

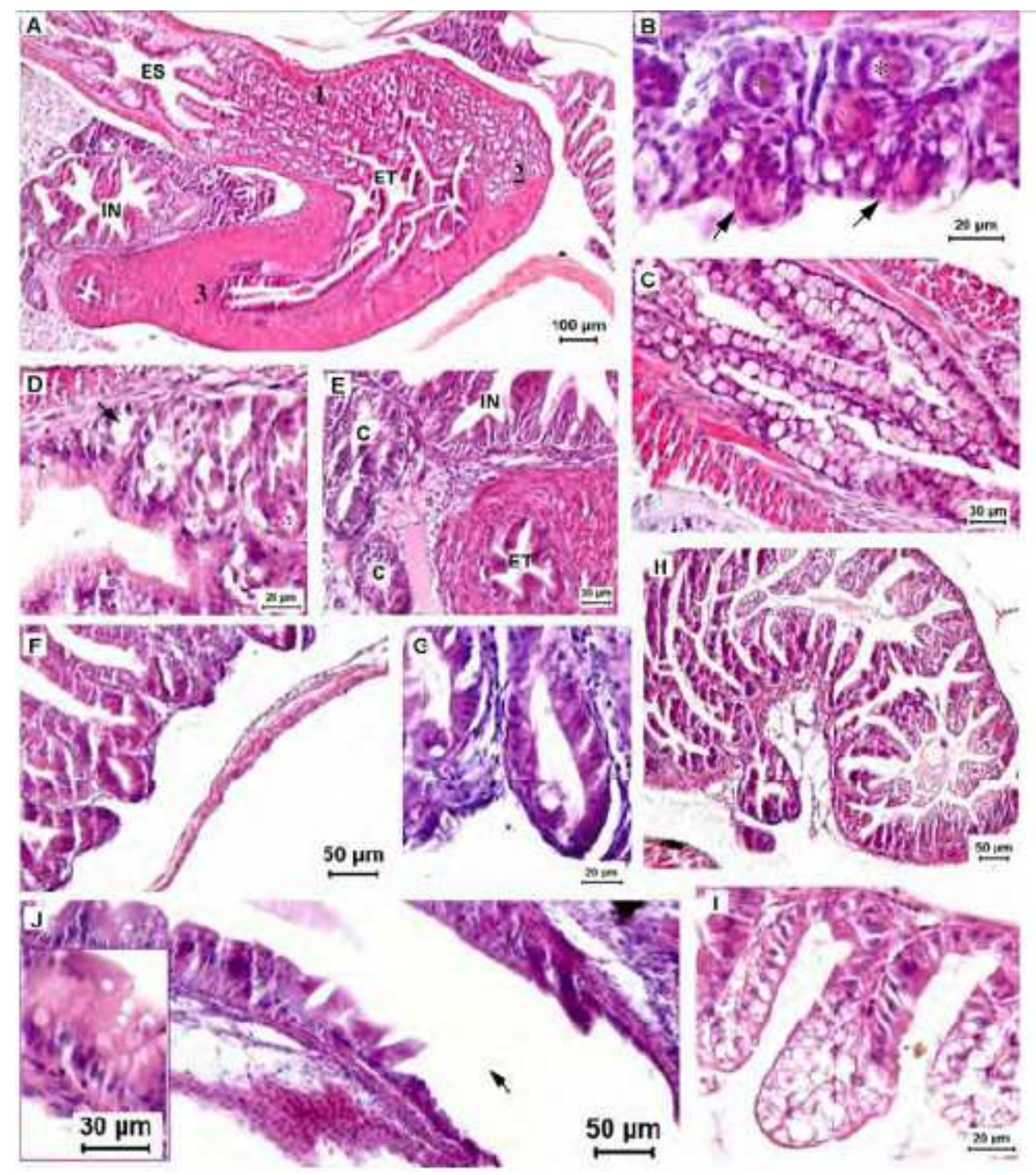

Figura 5. Fotomicrografia do trato digestório de B. amazonicus com 243 h Póseclosão. A - vista panorâmica do esôfago (ES), estomago (ET), com porção cardíaca (1), cecal (2) e pilórica (3), e intestino médio (IN); B - alvéolos dentários (*) e botões gustativos (seta) no teto da faringe; C - esôfago; D -glândulas estomacais (seta); E lume da porção pilórica do estomago (ET), intestino (IN) e cecos pilórico (C); F e G cecos pilóricos; $\mathrm{H}$ - vista panorâmica do intestino médio; I - porção distal do intestino médio; J - reto e ânus (seta), com detalhe de células com aspecto mucoso.

Fonte: Freitas (2010) 
GADELHA, E.S. e ARAÚJO, J.C. Criação de Matrinxã em cativeiro. PUBVET, Londrina, V. 7, N. 5, Ed. 228, Art. 1507, Março, 2013.

\section{PARÂMETROS AMBIENTAIS}

Os parâmetros físico-químicos da água são fatores determinantes para o cultivo do animal em cativeiro, ou até mesmo em vida livre, o que pode determinar o seu habitat. A faixa de tolerância a esses parâmetros (oxigênio dissolvido, temperatura, $\mathrm{pH}$, alcalinidade, amônia total, turbidez, dureza e condutividade) depende de cada organismo animal, no caso da espécie foco deste trabalho, foi calculado a média de cada parâmetro (figura 6) que foi encontrado na literatura. Os parâmetros analisados para matrinxã alcançaram níveis mínimos e máximos, respectivamente: oxigênio $2,03 \mathrm{mg} / \mathrm{L}^{-1}$ e 73,5 $\mathrm{mg} / \mathrm{L}^{-1}$; temperatura, $22,46{ }^{\circ} \mathrm{C}$ e $30,86{ }^{\circ} \mathrm{C} ; \mathrm{pH} \quad 5,64$ e 8 ; alcalinidade 8,13 $\mathrm{mg} / \mathrm{L}$ e $87,82 \mathrm{mg} / \mathrm{L}$; turbidez 2,11 NTU e $50 \mathrm{NTU}$; amônia 0,03 mg/L e 0,64 $\mathrm{mg} / \mathrm{L}$; e condutividade 45 e 140,33. Para a maioria dos peixes neotropicais, a concentração mínima de oxigênio dissolvido para o cultivo deveria ser superior a $4,0 \mathrm{mg} / \mathrm{L}^{-1}$, níveis inferiores tornariam o meio estressante e comprometeriam o crescimento (GOMES e URBINATI, 2005). Como estudos que avaliam a tolerância a níveis críticos de oxigênio dissolvido para matrinxã são inexistentes, torna-se difícil afirmar que os níveis registrados foram críticos (PEDREIRA et al., 2010).

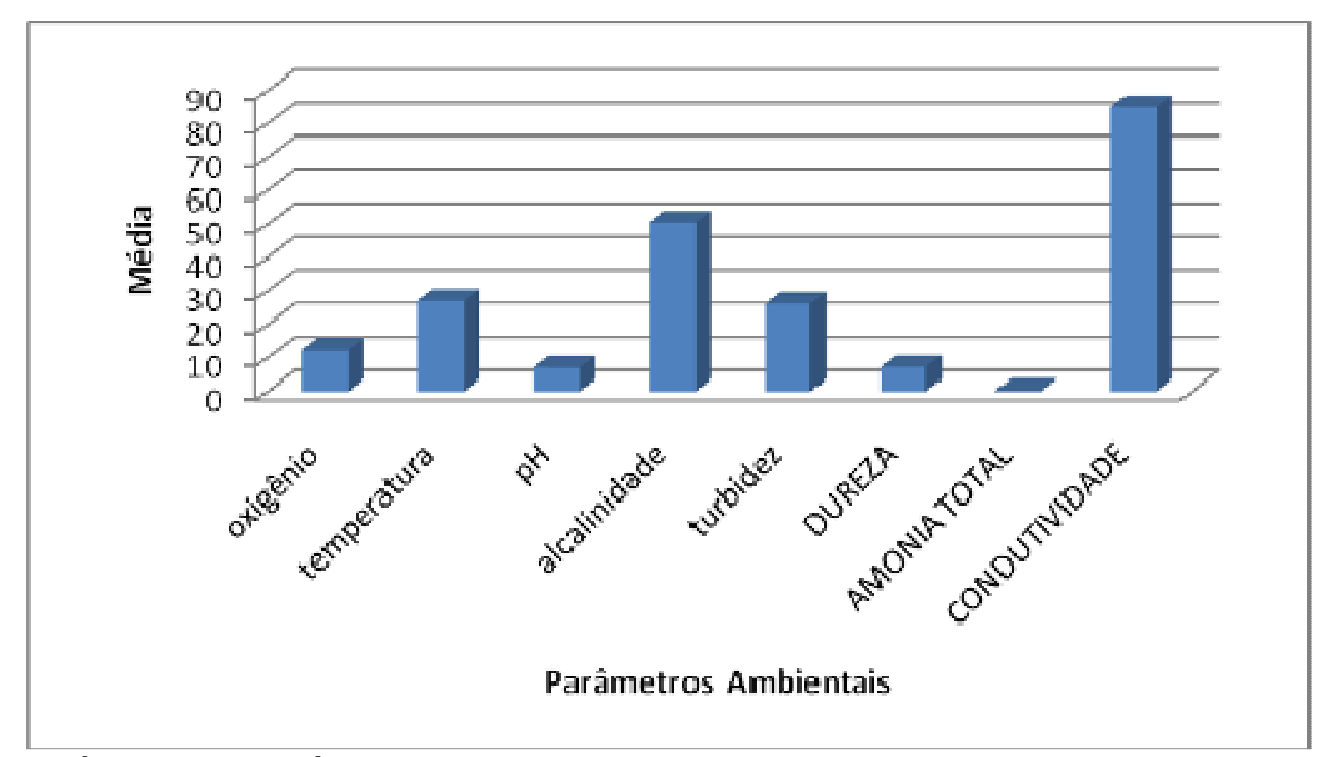

Figura 6. Média dos parâmetros ambientais, ideais para matrinxã, encontrado nas literaturas. 
GADELHA, E.S. e ARAÚJO, J.C. Criação de Matrinxã em cativeiro. PUBVET, Londrina, V. 7, N. 5, Ed. 228, Art. 1507, Março, 2013.

Tabela 1. Valores médios dos parâmetros físico-químicos da água encontrados na literatura.

\begin{tabular}{|c|c|c|c|c|}
\hline $\begin{array}{l}\text { Oxigênio } \\
\left(\mathrm{mg} / \mathrm{L}^{-1}\right)\end{array}$ & $\begin{array}{c}\text { Temperatura } \\
\left({ }^{\circ} \mathrm{C}\right)\end{array}$ & pH & $\begin{array}{l}\text { Alcalinidade } \\
(\mathrm{mg} / \mathrm{L})\end{array}$ & Autor \\
\hline 6,92 & 27,74 & 7,25 & & Zanuzzo, 2010 \\
\hline 73,5 & 24,5 & 6,9 & 51,4 & Dias et al., 2011 \\
\hline 3,9 & 22,46 & 8 & 27,67 & $\begin{array}{c}\text { Frascá-Scorvo et al., } \\
2001\end{array}$ \\
\hline 5 & 28,9 & & & $\begin{array}{l}\text { Arbeláez-Rojas et al., } \\
2002\end{array}$ \\
\hline \multirow[t]{3}{*}{6,4} & 26,6 & 7 & & Oda, 2009 \\
\hline & 28 & & & Freitas, 2010 \\
\hline & 24.98 & & & $\begin{array}{l}\text { Carvalho e Urbinati, } \\
2005\end{array}$ \\
\hline 2,72 & 24,28 & 6,49 & & Pedreira et al., 2010 \\
\hline 6,06 & 30,86 & 5,64 & 8,13 & Brandão et al., 2005 \\
\hline 6,70 & 28,08 & 6,80 & 77,33 & Neumann, 2008 \\
\hline 6,49 & 30,07 & 7,65 & 87,82 & Neumann, 2008 \\
\hline 5,8 & 26 & 7,2 & & Pedreira et al., 2008 \\
\hline
\end{tabular}

Tabela 2. Valores médios dos parâmetros físico-químicos da água encontrados na literatura.

\begin{tabular}{|c|c|c|c|c|}
\hline $\begin{array}{l}\text { Turbidez } \\
\text { (NTU) }\end{array}$ & $\begin{array}{c}\text { Dureza (mg } \\
\left.\mathrm{L}^{-1}\right)\end{array}$ & $\begin{array}{c}\text { Amônia } \\
\text { total } \\
\text { (mg/L) }\end{array}$ & $\begin{array}{l}\text { Condutividade } \\
\qquad\left(\mu \mathrm{Sm}^{-1)}\right.\end{array}$ & Autor \\
\hline & & 0,03 & & Zanuzzo, 2010 \\
\hline \multirow[t]{2}{*}{50} & & & & $\begin{array}{c}\text { Frascá-Scorvo } \\
\text { et al., } 2001\end{array}$ \\
\hline & & & 45 & $\begin{array}{c}\text { Arbeláez-Rojas } \\
\text { et al., } 2002\end{array}$ \\
\hline \multirow[t]{5}{*}{2,11} & & & 140,33 & $\begin{array}{c}\text { Pedreira et al., } \\
2010\end{array}$ \\
\hline & 7,13 & 0,29 & & $\begin{array}{c}\text { Brandão et al., } \\
2005\end{array}$ \\
\hline & & 0,061 & & Neumann, 2008 \\
\hline & & 0,64 & & Neumann, 2008 \\
\hline & & & 69,7 & $\begin{array}{c}\text { Pedreira et al., } \\
2008\end{array}$ \\
\hline
\end{tabular}


GADELHA, E.S. e ARAÚJO, J.C. Criação de Matrinxã em cativeiro. PUBVET, Londrina, V. 7, N. 5, Ed. 228, Art. 1507, Março, 2013.

\section{PROPORÇÃO SEXUAL}

Para a criação em cativeiro, Arias et al. (2006) constataram que a espécie $B$. amazonicus possui uma proporção sexual de 1,85 fêmeas para 1 macho. B. cephalus em seu habitat natural apresenta uma proporção sexual de 1:1,2 com predomínio de machos (ZANIBONI FILHO, 1985), contudo quando em cativeiro esta apresenta uma proporção de 9,3:1, com predomínio de fêmeas (ROMAGOSA, 1998). Tal variação de proporção sexual em uma mesma espécie deve-se ao fator ambiental (principalmente oferta de alimento), onde este apresentará uma característica própria para cada local, o que por consequência influencia na migração e consequentemente na reprodução.

\section{COMPORTAMENTO REPRODUTIVO}

Como comportamento reprodutivo o matrinxã realiza migração (reofilíco), acompanhando o período de vazante e enchente dos rios, apresenta fecundação e desenvolvimento externo, sem cuidado parental, esta espécie libera um grande número de pequenos ovos na coluna de água, adquirindo rapidamente um grande espaço perivitelino com provável função de proteção mecânica ao embrião, passando por um curto período de desenvolvimento embrionário e larval (ROMAGOSA, 2001; NEUMANN, 2008). Sua desova é sincrônica, isto é, inúmeros óvulos, pequenos, são liberados em conjunto (ROMAGOSA et al., 2001). Zaniboni - Filho e Resende (1988) relatam o período reprodutivo desta espécie em ambiente natural entre os meses de dezembro e janeiro, obedecendo ao período das enchentes da região amazônica, contudo, Gonçalves et al. (2006) discorrem que B. orthotaenia inicia seu período de desova em outubro com término em janeiro. $O$ início da temporada das cheias caracteriza-se por rápidas mudanças no ambiente aquático, o que determina o momento para a reprodução dos peixes que realizam migração (JIMÉNEZ-SEGURA, 2000). Levando em consideração as características reprodutivas deste peixe, pode-se concluir que este é um estrategista r. O matrinxã, do gênero masculino, atinge a sua primeira maturação sexual logo no primeiro ano de vida e comprimento padrão a partir 
GADELHA, E.S. e ARAÚJO, J.C. Criação de Matrinxã em cativeiro. PUBVET, Londrina, V. 7, N. 5, Ed. 228, Art. 1507, Março, 2013.

de 41,6 cm, enquanto que, a fêmea somente no segundo ano de vida e com comprimento padrão de $31 \mathrm{~cm}$ (ZANIBONI FILHO, 1985; GONÇALVES et al., 2006; NEUMANN, 2008).

\section{MIGRAÇÃO}

Zaniboni Filho (1985) dividiu os movimentos migratórios do matrinxã em 6 tipos (fases), que são: Baixada para desova; Rio acima pós-desova; Baixada do peixe gordo; Arribação; Período de pré-desova; e Área de criação, que serão detalhadas a seguir.

A Baixada para a desova (migração reprodutiva) ocorre entre os meses de dezembro e fevereiro (inicio das enchentes), esta migração acontece preferencialmente durante o dia. Os cardumes são compostos quase que exclusivamente por adultos em estágio avançado de desenvolvimento gonadal.

A fase Rio acima pós-desova (migração trófica) consiste na aparentemente migração após a desova para locais onde haja abundância de alimento, seguindo em movimentos ascendentes ou laterais para exploração de novos ambientes, fase esta que inicia entre janeiro e abril.

Baixada do peixe gordo, nesta fase os cardumes, compostos por indivíduos jovens e adultos em repouso gonadal e com grande reserva lipídica na cavidade visceral, retornam para o seu antigo habitat. Isto ocorre no inicio do período de vazante, entre os meses de abril e agosto.

Já a Arribação, movimento migratório, que ocorre entre agosto e setembro, no período de vazante, os cardumes são compostos por indivíduos jovens, com depósito de gordura reduzido.

Período de pré-desova, nesta fase os indivíduos jovens e adultos alojamse preferencialmente no curso médio dos igarapés, em poços e corredeiras, procurando durante a noite áreas tranquilas. Os teleósteos adultos iniciam neste período (outubro a dezembro) de seca, a maturação gonadal.

A Área de criação acontece nos períodos de enchente-cheia (janeiro e julho), esta fase caracteriza-se pela formação de lagos de várzea, onde alojam-se os indivíduos nascidos na última desova. Quando inicia a vazante, 
GADELHA, E.S. e ARAÚJO, J.C. Criação de Matrinxã em cativeiro. PUBVET, Londrina, V. 7, N. 5, Ed. 228, Art. 1507, Março, 2013.

estes saem desses lagos e executam movimentos em direção aos tributários de águas pobres.

\section{FECUNDIDADE}

O matrinxã apresenta uma alta fecundidade, a produção de óvulos é ao redor de 10 - 15\% do peso vivo das fêmeas e, a quantidade de esperma dos machos é grande, se comparada, por exemplo, com o pacu e o tambaqui. Apenas o líquido espermático de um macho é suficiente para fecundar óvulos de duas a três fêmeas (CECARELLI e SENHORINI, 1996). A fecundação em cativeiro varia entre 24.523 a 434.263 ovos (ROMAGOSA et al., 2006). Contudo, a fecundação em vida livre varia de 36.706 a 309.287 ovócitos (ZANIBONI FILHO, 1985). Tal fecundidade vai depender de cada organismo e da homeostase, quando em cativeiro o manejo inadequado pode corroborar para uma baixa fecundidade.

\section{CICLO DE VIDA/FASES}

O matrinxã apresenta estágio embrionário de 40 minuntos pós fertilização, as larvas eclodem aproximadamente 10-11 horas após fertilização, o seu desenvolvimento pode ser visto na figura 7, a metamorfose termina praticamente 36 horas após a fertilização, com estruturas semelhantes às do exemplar adulto, sendo alcançada 48 horas após a fertilização, em outras palavras, a matrinxã apresenta três fases durante o seu ciclo de vida: a fase embrionária, a fase larval, a juvenil (alevino) e a adulta (ROMAGOSA et al., 2001). Diferente de Romagosa et al. (2001), Neumann (2008) separou as fases larvais em fases de desenvolvimento segundo Kendall Jr. et al. (1983), modificado por Nakatani et al. (2001), de acordo com o grau de flexão da notocorda e desenvolvimento dos elementos de sustentação da nadadeira caudal, como descrito a seguir: 1- larval vitelino (LV): estágio entre a eclosão e o inicio da alimentação exógena (abertura do ânus e da boca); 2- pré-flexão (PrF): se estende desde o inicio da alimentação exógena até o início da flexão da região terminal da notocorda; 3- flexão (FL): caracteriza-se pelo inicio de 
GADELHA, E.S. e ARAÚJO, J.C. Criação de Matrinxã em cativeiro. PUBVET, Londrina, V. 7, N. 5, Ed. 228, Art. 1507, Março, 2013.

flexão da notocorda e aparecimento dos elementos de sustentação da nadadeira caudal até a completa flexão da região terminal da notocorda e aparecimento da nadadeira pélvica; 4- pós-flexão (PoF): inicia-se após total flexão da região terminal da notocorda, completa formação dos ossos hipurais e raios na nadadeira caudal e aparecimento do botão da nadadeira pélvica. Além dos estágios larvais, o período juvenil (JV), estende-se desde a total formação dos raios nas nadadeiras e de escamas, absorção da nadadeira embrionária, até a primeira maturação sexual do individuo, tais fases podem ser visualizadas na figura 8 . 


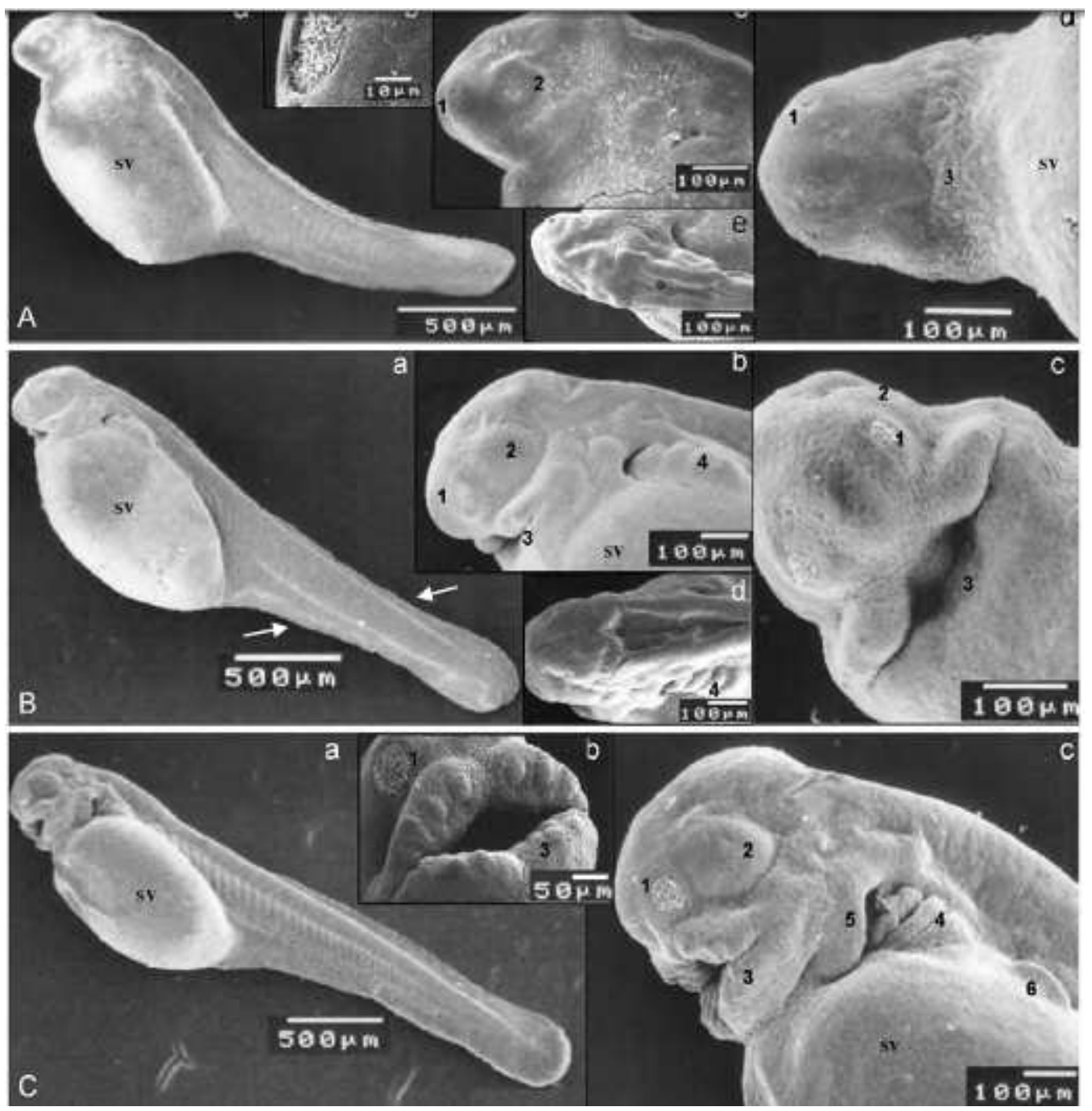

Figura 7. Eletronmicrografia do desenvolvimento larval de 0 a $11 \mathrm{~h}$ pós-eclosão (PE) em B. amazonicus. Eclosão: A.a - vista lateral completa; A.b - placa olfatória; A.c vista lateral da região anterior; A.d - vista ventral da cabeça; A.e - vista dorsal da região anterior. 4 h PE: B.a - vista lateral completa e membrana embrionária (seta); B.b - vista lateral da região anterior; B.c - vista ventral da cabeça; B.d - vista dorsal da região anterior. 11 h PE: C.a - vista lateral completa C.b - vista frontal da cabeça; C.c - vista lateral da região anterior. Placa olfatória (1), vesícula óptica (2), boca (3), arcos branquiais (4), opérculo (5) e botão da nadadeira peitoral (6), saco vitelino (sv), sulco cefálico (asterisco).

Fonte: Neumann (2008). 

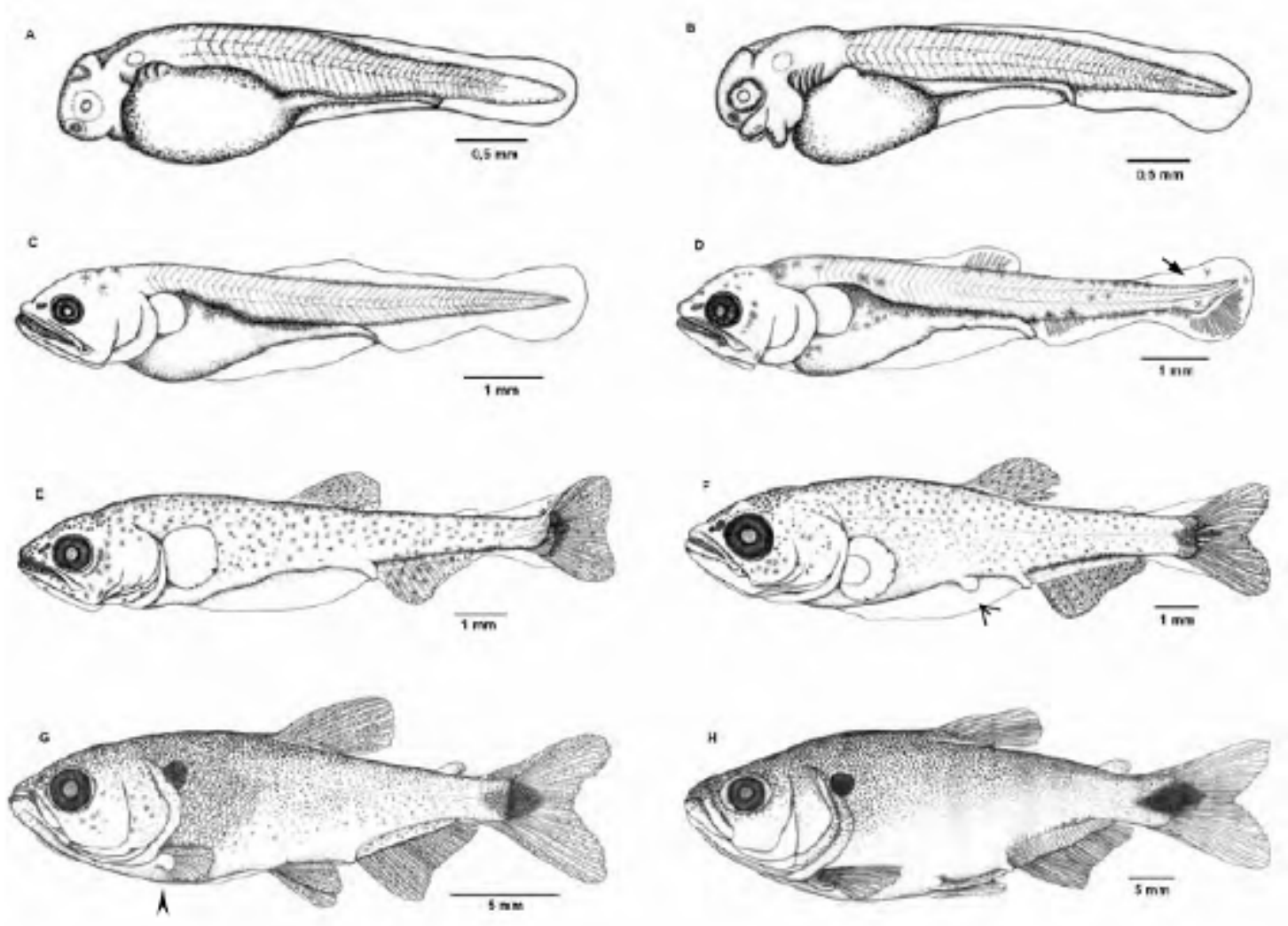

Figura 8. Estágios de desenvolvimento de B. amazonicus. A - 2 h PE: larval vitelino; B - 11 h PE: larval vitelino; C - 59 h PE: pré-flexão; D - 83 h PE: inicio de flexão; E 171 h PE: final de flexão; F - 243 h PE: inicio de pós-flexão; G - 411 h PE: final de pós-flexão; H - 583 h PE: juvenil. Flexão da notocorda (seta cheia), botão da nadadeira pélvica (seta vazada) e inserção membranosa da nadadeira peitoral (ponta de seta).

Fonte: Neumann (2008).

\section{DIETA EM CATIVEIRO}

Em cativeiro as larvas aceitam ração artificial a partir do $4^{\circ}$ dia de vida, além de ração as larvas podem receber alimentos vivos, o que também diminui a taxa de canibalismo. O manejo da primeira alimentação das pós-larvas (PL) de matrinxã, durante vinte e quatro horas com alimento vivo, antes de serem estocadas em viveiros adubados organicamente para a alevinagem, produz melhor sobrevivência (ATENCIO-GARCÍA et al., 2003; LEONARDO, 2005). A implementação de precursores hormonais também auxilia na redução do 
GADELHA, E.S. e ARAÚJO, J.C. Criação de Matrinxã em cativeiro. PUBVET, Londrina, V. 7, N. 5, Ed. 228, Art. 1507, Março, 2013.

canibalismo, segundo os resultados de Hoshiba (2007), o enriquecimento da ração com 5,39 g de tirosina/100 gramas de ração, promove um maior crescimento em comprimento e peso, redução de canibalismo e sobrevivência larval.

A tirosina pode ser usada como precursor dos hormônios tireoidianos, estimulando a produção hormonal e causando, de forma indireta, os mesmos benefícios do seu uso. O matrinxã digere igualmente proteína de origem animal e vegetal, sendo que, $35 \%$ de proteína bruta (PB) e $3.200 \mathrm{kcal}$ de energia metabolizável $/ \mathrm{kg}$ podem ser suficientes para atender às exigências nutricionais desta espécie (MENDONÇA et al., 1993), entretanto, Izel et al. (2004) testaram níveis inferiores de proteína, e constataram que animais com peso a partir de $250 \mathrm{~g}$ alimentados com 28\% de proteína bruta apresentam bom ganho de peso e boa conversão alimentar, enquanto os ingredientes milho, farelo de trigo e farinha de peixe, apresentam digestibilidade aparente de matéria seca, respectivamente de 52,3\%, 54\% e 54,5\% (SALLUM et al., 2002).

Segundo Honczaryk (1999) a espécie tem preferência alimentar no período da tarde, quando o oxigênio dissolvido e a temperatura estiverem alta. Reimer (1982) constatou que o matrinxã apresenta capacidade de adaptar seu metabolismo ao tipo de nutriente presente nas dietas, aumentando a atividade das enzimas digestivas em função do substrato de alimento ofertado (proteína, carboidrato ou gordura). Devido a essa característica, o matrinxã pode aproveitar eficientemente gorduras, carboidratos e proteínas como fonte de energia para realizar suas funções biológicas.

\section{REPRODUÇÃO EM CATIVEIRO}

Peixes que realizam migração, incluindo o matrinxã, não se reproduzem em condições de cativeiro, pois a ovogênese e a desova não se completam, a não ser que sejam estimuladas artificialmente por aplicação de hormônios, sendo os mais utilizados: o LHRH, extrato de hipófise de carpa (EPC) e GnRH (BERNARDINO et al., 1993; GOMES e URBINATI, 2005). Dias et al. (2011) 
GADELHA, E.S. e ARAÚJO, J.C. Criação de Matrinxã em cativeiro. PUBVET, Londrina, V. 7, N. 5, Ed. 228, Art. 1507, Março, 2013.

adicionaram probiótico (Bacillus subtilis) na alimentação deste teleósteo, o que otimizou os valores da taxa de fertilização e taxa de eclosão de fêmeas. No período reprodutivo, os machos apresentam aspereza nas nadadeiras ventrais e anais, e sob leve pressão no abdômen liberam líquido espermático enquanto as fêmeas, quando aptas a responderem a indução hormonal (desova), apresentam abaulamento e flacidez na região abdominal além de apresentar uma coloração rosada na papila genital (CECCARELLI e SENHORINI, 1996). Ponzetto et al. (2009) realizaram o cruzamento matrinxã x matrinxã, matrinxã x piracanjuba e matrinxã x piraputanga, gerando híbridos que apresentaram heterose, ou seja, apresentaram melhor desempenho produtivo que os pais, sendo aptos a produção em cativeiro. Segundo Ceccarelli e Senhorini (1996) para se aplicar O EPC deve se seguir o seguinte protocolo: as fêmeas devem receber de quatro a cinco $\mathrm{mg} / \mathrm{kg}$, dividido em duas doses, através de injeção intra peritoneal, atrás da nadadeira peitoral. Na primeira, injeta-se $20 \%$ do total e na segunda os $80 \%$ restantes, de 8 a 12 horas após a primeira injeção. Nos machos, aplica-se uma única dose de $0,5 \mathrm{mg} / \mathrm{kg}$ (machos mais abundantes) ou $1,0 \mathrm{mg} / \mathrm{kg}$ (machos mais atrasados) no mesmo horário da aplicação da segunda dose das fêmeas. Lembrando que deve-se tomar cuidado na administração de hormônios, pois o seu uso inadequado pode ter consequências na sanidade humana e animal.

O matrinxã logo após a eclosão, cerca de 30 a 35 horas, tornam-se canibais (figura 9), resultando em até $99 \%$ de perda, tendo o acréscimo de larvas de pacu diminuído significativamente a taxa de canibalismo. 
GADELHA, E.S. e ARAÚJO, J.C. Criação de Matrinxã em cativeiro. PUBVET, Londrina, V. 7, N. 5, Ed. 228, Art. 1507, Março, 2013.
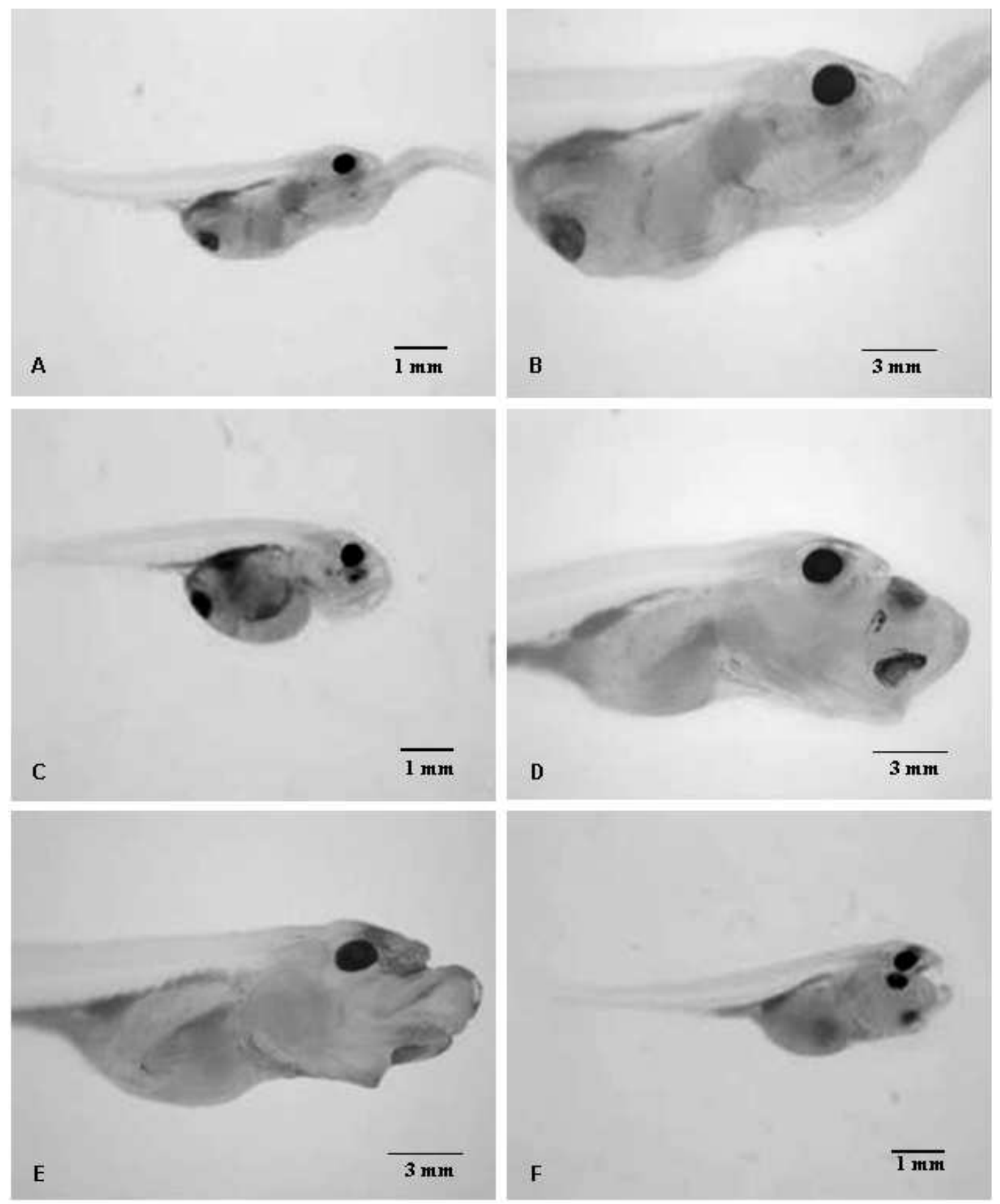

Figura 9. Fotomicrografia de larva de matrinxã, Brycon cephalus. A) Canibalismo no sentido cabeça - cauda. B) Detalhe mostrando a ingestão e evidenciando a pigmentação dos olhos. C) Larva já ingerida a posição dos olhos indicando o sentido da predação. D) Canibalismo no sentido cauda - cabeça, com predação lateral. E) Larva sendo parcialmente engolida. F) Presa sendo engolida pelo predador evidenciando o canibalismo.

Fonte: Leonardo et al. (2008). 
GADELHA, E.S. e ARAÚJO, J.C. Criação de Matrinxã em cativeiro. PUBVET, Londrina, V. 7, N. 5, Ed. 228, Art. 1507, Março, 2013.

\section{MORFOMÉTRIA}

O matrinxã é um peixe que quando adulto pode chegar a um comprimento total de $80 \mathrm{~cm}$ e pesar cerca de $5 \mathrm{~kg}$. Na fase juvenil ele alcança um comprimento de $22,8 \mathrm{~cm}$ e um peso de $0,148 \mathrm{~kg}$, os dados encontrados na literatura sobre a relação morfométrica (peso-comprimento) deste peixe encontram-se nesta tabela 3.

Tabela 3. Relação morfométrica (peso-comprimento total) encontrados nas literaturas.

\begin{tabular}{cccc}
\hline $\begin{array}{c}\text { Peso } \\
\mathbf{( k g )}\end{array}$ & $\begin{array}{c}\text { Comprimento total } \\
\mathbf{( c m})\end{array}$ & Espécie & Autor \\
\hline $\mathbf{4}$ & 60 & Brycon amazonicus (adulto) & Zenaid, 2011 \\
$\mathbf{5}$ & 80 & $\begin{array}{c}\text { Brycon amazonicus (adulto) } \\
\text { Brycon amazonicus (adulto) }\end{array}$ & Lima, 2003 \\
$\mathbf{4} \mathbf{5}$ & 50 & $\begin{array}{c}\text { Brycon amazonicus (20 ano } \\
\text { de vida) }\end{array}$ & Freitas, 2010 \\
$\mathbf{0 , 9 7}$ & 45,5 & Brycon orthotaenia (juvenil) & $\begin{array}{c}\text { Pedreira et al., } \\
2010\end{array}$ \\
$\mathbf{0 , 0 9}$ & 19,9 & Brycon orthotaenia (juvenil) & $\begin{array}{c}\text { Pedreira et al., } \\
2010\end{array}$ \\
$\mathbf{0 , 1 4}$ & 22,8 & Brycon orthotaenia (juvenil) & $\begin{array}{c}\text { Pedreira et al., } \\
2010\end{array}$ \\
$\mathbf{0 , 1 3}$ & 22,3 & & Brandão et al., \\
$\mathbf{0 , 0 6}$ & & Brycon amazonicus (juvenil) & 2005 \\
$\mathbf{2 , 1 0}$ & 16,57 & Brycon amazonicus (adulto) & Neumann, 2008 \\
$\mathbf{5}$ & 48,10 & Brycon amazonicus (adulto) & Val e \\
\hline & 80 & & Honczarik,1995 \\
\hline
\end{tabular}

\section{CONCLUSÃO}

O matrinxã tem se mostrado um peixe nativo bastante promissor na piscicultura, isso se justifica quando se observa a sua biologia, por ser estrategista $r$ apresenta um período de vida curto, o que propicia um crescimento rápido e possui fecundidade elevada, entretanto, ainda são 
GADELHA, E.S. e ARAÚJO, J.C. Criação de Matrinxã em cativeiro. PUBVET, Londrina, V. 7, N. 5, Ed. 228, Art. 1507, Março, 2013.

escassos estudos que contribuam para melhoria do canibalismo na larvicultura, muitos experimentos têm surgido neste sentido, porém ou não conseguem êxito, ou a taxa de sobrevivência das larvas não condiz com os gastos com alimentação adequada. Nesse contexto, a aplicação de hormônios se mostrou efetiva na diminuição do canibalismo, contudo seus efeitos na sanidade humana devem ser avaliados. É necessário ainda, gerar informações acerca da digestibilidade deste animal, visando diminuir os gastos com a nutrição e a poluição ambiental.

\section{REFERÊNCIAS BIBLIOGRÁFICAS}

ANELLI JUNIOR, L. C. Efeitos de diferentes formulações comerciais do herbicida Roundp sobre a função cardiorespiratória de matrinxã, Brycon amazonicus (Teleostei, Characidae). Tese. Universidade Federal de São Carlos. 2010: 91.

ARBELÁEZ-ROJAS, G. A.; FRACALOSSI, D. M.; FIM, J. D. I. Composição corporal de tambaqui, Colossoma macropomum, e matrinxã, Brycon cephalus, em sistemas de cultivo Intensivo, em igarapé, e semi-intensivo, em viveiros. R. Bras. Zootec., 2002; 31(3):1059-1069.

ARBELÁEZ-ROJAS, G. A.; MORAES, G. Interação do exercício de natação sustentada e da densidade de estocagem no desempenho e na composição corporal de juvenis de matrinxã Brycon amazonicus. Ciência Rural, 2009; 39(1): 201-208.

ARIAS, C. J. A.; ZANIBONI-FILHO, E.; AYA, B. E. Indicadores Del ciclo reproductivo del yamú Brycon amazonicus, en cautiverio. Revista Orinoquia, 2006; 10(2): 24-34.

ATENCIO-GARCÍA, V.; ZANIBONI-FILHO, E.; PARDO-CARRASCO, S.; ARIAS-CASTELLANOS, A. Influência da primeira alimentação na larvicultura e alevinagem do yamú Brycon siebenthalae (Characidae). Animal Sciences,2003; 25(1): 61-72.

BERNARDINO, G.; SENHORINI, J. A.; FONTES, N. A.; BOCK, C. L.; MENDONÇA, J. O. J. Propagação artificial do matrinxã, Brycon cephalus (Gunther, 1869), (Teleostei, Characidae). Boletim Técnico do CEPTA, 1993; 6(2): 1-10.

BRANDÃO, F. R.; GOMES, L. C.; DANTAS, L.; SILVA, A. L. F.; CHAGAS, E. C. Densidade de estocagem durante a recria do matrinxã em tanque-rede. Pesquisa Agropecuária Brasileira, $2005 ; 40(3)$.

BRITSKI, H. A.; SILIMON, K. S. S.; LOPES, B. S. Peixes do Pantanal: Manual de Identificação. Brasília: EMBRAPA - SPI, p. 184. 1999.

CARVALHO, E. G.; URBINATI, E. C. Crescimento, desenvolvimento gonadal e composição muscular de matrinxãs (Brycon cephalus) submetidos à restrição alimentar e realimentação durante um ano. Ciência Rural, 2005; 35(4): 897-902.

CASTAGNOLLI, N. Criação de peixes de água doce. Jaboticabal: FUNEP. 1992.189p. 
CECCARELLI, P. S.; SENHORINI, J. A. Brycon viabilização da produção de alevinos. Panorama da aquicultura, 1996; 6(35): 10-11.

DIAS, D. C.; FURLANETO, F. P. B.; AYROZA, L. M. S.; TACHIBANA, L.; LEONARDO, A. F. G.; CORRÊA, C. F.; ROMAGOSA, E.; RANZANI-PAIVA, M. J. T. Utilização de probiótico na dieta de reprodutoras de matrinxã (Brycon amazonicus). Bol. Inst. Pesca, 2011; 37(2): 135 - 141.

FAUSTINO, F.; NAKAGHI, L. S. O.; NEUMANN, E. Brycon gouldingi (Teleostei, Characidae): aspects of the embryonic development in a new fish species with aquaculture potential. Zygote, 2010; 19: 351-363.

FERREIRA, E. J. G.; ZUANON, J. A. S.; SANTOS, G. M. Peixes comerciais do médio Amazonas: região de Santarém, Pará. Brasília, 1998, p. 93. Edições IBAMA. Fisher Base. Disponível em: <http://www.fishbase.org/Photos/ThumbnailsSummary.php?ID=25516>. Acessado em: 15/10/11 11:10.

FIM, J. D. I. Sistema integrado de cultivo entre animais e peixes. In: VAL, A. L.; HONCZARYK, A. Criando peixes na Amazônia. Manaus: Instituto Nacional de Pesquisas da Amazônia, p. 149. 1995.

FRASCÁ-SCORVO, C. M. D.; CARNEIRO, D. J.; MALHEIROS, E. B. Comportamento alimentar do matrinxã (Brycon cephalus) no período de temperaturas mais baixas. Boletim do Instituto de Pesca, 2001; 27(1): 1-5.

FREITAS, F. L. Crescimento e reprodução da matrinxã Brycon amazonicus em tanques no município de Paulo Afonso, Bahia. Dissertação. Universidade Federal Rural de Pernambuco. 2010: 46.

GOMES, L. C.; BALDISSEROTTO, B.; SENHORINI, J. A. Efeito da densidade de estocagem na qualidade da água, sobrevivência e crescimento das larvas do matrinxã, Brycon cephalus (Characidae), em lagoas. Aquicultura, 2000; 183: 73-81.

GOMES, L. C.; URBINATI, E. C. Matrinxã (Brycon amazonicus). In: BALDISSEROTTO, B.; GOMES, L.C. Espécies nativas para piscicultura no Brasil. 2a ED. Santa Maria: UFSM, 2005: 149-174.

GONÇALVES, T. L.; BAZZOLI, N.; BRITO, M. F. G. Gametogenesis and reproduction of the matrinxã Brycon orthotaenia (Günther, 1864) (pisces: characidae) in the são francisco river, Minas Gerais, Brazil. Braz. J. Biol., 2006; 66(2): 513-522.

GOULDING, M. Ecologia da pesca do rio Madeira. Manaus: INPA, 1979. 172p.

Habtec: Engenharia Ambiental. Disponível em:

<http://www.habtec.com.br/experiencia/clientes/santa-gisele/pch-bacuri/>. Acessado em: $15: 33$ 21/08/11.

HONCZARYK, A. O potencial do Matrinxã, Brycon cephalus, na piscicultura da Amazônica. In: CONFERÊNCIA INTERNACIONAL AMAZÔNIA NO TERCEIRO MILÊNIO: ATITUDES DESEJÁVEIS, 1999, Manaus. Anais... Amazonas, 1999. p. 24-27.

HOSHIBA, M. A. Enriquecimento da alimentação das larvas de matrinxã (Brycon amazonicus) com aminoácidos: Influência no crescimento inicial e sobrevivência das larvas. Dissertação. Universidade do Estadual Paulista. 2007:103. 
HOSHIBA, M. A.; GONÇALVES, F. D.; URBINATI, E. C. Respostas fisiológicas de estresse no matrinxã (Brycon amazonicus) após exercício físico intenso durante a captura. Acta Amazonica, 2009; 39(2): 445 - 452.

IBAMA. Instituto Brasileiro do Meio Ambiente e dos Recursos Naturais Renováveis. Estatística da Aqüicultura e Pesca no Brasil - Ano 2007. Brasil: Grandes regiões e unidades da federação. Brasília: IBAMA/Ministério do Meio Ambiente, 2007. 151 p. Disponível em: <http://www.mpa.gov.br/mpa/seap/Jonathan/mpa3/info-estatistica/docs/Estatistica-daAquicultura-e-Pesca-no- Brasil-2007.pdf>. Acessado em: 25/08/11 00:07.

IZEL, A. C. U.; PEREIRA-FILHO, M.; MELO, L. A. S.; MACÊDO, J. L. V. de. Avaliação de níveis protéicos para a nutrição de juvenis de matrinxã (Brycon cephalus). Rev. Acta Amazonica, 2004; 34(2): 179-184.

JIMÉNEZ - SEGURA, L. F. Distribuição horizontal do ictioplancton no médio São Francisco, MG, Brasil. Tese. Universidade Federal de Minas Gerais. 2000: 110.

LEITE, R. G.; ARAúJO LIMA, C. A. R. M. Feeding of the Brycon amazonicum, Triportheus elongatus and Semaprochilodus insiginis (Osteichthyes, Characiformes), larvae in Solimões/Amazonas river and floodplain areas. Acta Amazonica, 2002; 32(3): 56-67.

LEITE, R. G. A alimentação de juvenis de matrinxã, Brycon amazonicum (Pisces, Characidae),em áreas inundadas da Ilha de Marchantaria, Amazonas, Brasil. Rev. Acta Amazonica, 2004; 34(4): 661-664.

LEONARDO, A. F. G. Ação da triiodotironina na larvicultura da piracanjuba (Brycon orbignyanus) e matrinxã (Brycon cephalus). Tese. Universidade Estadual Paulista. 2005: 81.

LEONARDO, A. F. G.; HOSHIBA, M. A.; SENHORINI, J. A.; URBINATI, E. C. Canibalismo em larvas de matrinxã, Brycon cephalus, após imersão dos ovos à diferentes concentrações de triiodotironina $\left(\mathrm{t}_{3}\right)$. B. Inst. Pesca, 2008; 34(2): 231-239.

LIMA, F.C.T. Subfamily Bryconinae (Characins, Tetras). In: REIS, R.E; KULANDER, S.O; FERRARIS JR, C.J. (Orgs). Check List of the Freshwater Fishes of South and Central America. Porto Alegre: EDPURCS, 2003, p.174-181.

LIMA, M. S. Os fluxos de conhecimentos na piscicultura do estado do Amazonas: uma análise da trajetória e das condições institucionais. ConTexto, 2005; 5(8): 1676-6016.

MARQUES, N. R.; HAYASHI, C.; FURUYA, W. M.; SOARES, C. M. Influência da densidade de estocagem no cultivo de alevinos de matrinxã Brycon cephalus (Günther, 1869) em condições experimentais. Acta Scientiarum Biological Sciences, 2004; 26(1): 55-59.

MELO, K. S. G. Extração e uso de corantes vegetais da Amazônia no tingimento do couro de Matrinxã (Brycon amazonicus, Spix e Agassiz, 1819). Dissertação. Instituto Nacional de Pesquisas da Amazônia. 2007: 79.

MENDONÇA, J. O. J.; SENHORINI, J. A.; FONTES, N. A. Influência de fontes protéicas no crescimento de matrinchã, Brycon cephalus, em viveiro. Boletim Técnico do CEPTA, 1993; 6: 51-58.

MERONA, B.; BITTENCOURT, M. M. A pesca na Amazônia através dos desembarques do mercado de Manaus: resultados preliminares. Memorias de La Sociedad de Ciencias Naturales La Salle,1988; 48: 433-453. 
Ministério da Integração Nacional, Brasil. Relatório do censo estrutural da pesca de águas continentais da região norte. Brasília, 2006.

MINISTÉRIO DA PESCA E AQUICULTURA. Boletim estatístico da pesca e aquicultura: Brasil 2010. Brasília, 2012.

NEUMANN, E. Desenvolvimento inicial de jatuarana, Brycon amazonicus (teleostei, characidae). Tese. Universidade do Estadual Paulista. 2008: 108.

ODA, G. M. Cortisol na reprodução e no desenvolvimento inicial do matrinxã (Brycon amazonicus). Dissertação. Universidade do Estadual Paulista. 2009:68.

OSTRENSKY, A.; BORGHETTI, J. R.; SOTO, D. Aquicultura no Brasil: O desafio é crescer. Brasília, 276p. 2008.

PEDREIRA, M. M.; LUZ, R. K.; SANTOS, J. C. E. DOS; MATTIOLI, C. C.; SILVA, C. L. Larvicultura de matrinxã em tanques de diferentes cores. Pesq. agropec. bras., 2008; 43(10): 1365-1369.

PEDREIRA, M. M.; SAMPAIO, E. V.; SANTOS, J. C. E.dos; LUZ, R. K. Cultivo de matrinxã Brycon orthotaenia (Günther, 1864) em tanques-rede, em diferentes densidades de estocagem. Acta Scientiarum. Biological Sciences, 2010; 32(1): 17-22.

PONZETTO, J. M.; POLAZ, C. N. M.; GIMENES, R. C. Reprodução induzida de híbridos do gênero Brycon em cativeiro: potencialidades e ameaças à conservação das espécies nativas. In: VI Congresso de meio ambiente da AUGM, 2009, São Carlos, Anais... São Carlos: UFSCAR, 2009.

REIMER. G. The influence of diet on the digestive enzyme of the Amazon fish matrinxã, Brycon cf. melanopterum. Journal of Fish Biology, 1982; 21: 637-642.

ROMAGOSA, E.; AYROSA, L. M.; SCORVO FILHO, J. D. Crescimento e engorda do matrinxã, Brycon cephalus, (Gunther, 1869), em condições de confinamento, na região do Vale do Ribiera. Cepar, Instituto de Pesca, 1997: 31.

ROMAGOSA, E.; NARAHARA, M. Y.; FENERICH-VERANI, N. Stages of embryonic development of the "matrinxã", Brycon cephalus (pisces, characidae). Boletim do Instituto de Pesca, 2001; 27(1): 27-32.

SALLUM, W. B.; BERTECHINI, A. G.; CANTELMO, O. A.; PEZZATO, L. E.; LOGATO, P. R. V. Coeficiente de digestibilidade aparente da matéria seca, proteína bruta e extrato etéreo de ingredientes de ração para o matrinchã (Brycon cephalus, Günther 1869) (teleostei, characidae). Ciênc. Agrotec., 2002; 26(1): 174-181.

SANTOS FILHO, L. C. dos; BATISTA, V. S. Dinâmica populacional da matrinxã Brycon amazonicus (Characidae) na Amazônia Central. Zoologia, 2009; 26(2): 195-203.

SCORVO FILHO, J. D. Avaliação técnica e econômica das piscigranjas de três regiões do estado de São Paulo. Tese, Universidade Estadual Paulista. 1998: 98.

SILVA, S. A. A. da. Dieta natural de Brycon sp. n. "cristalino"- matrinxã no parque estadual cristalino, região norte de Mato Grosso, Brasil. Tese. Universidade do Estadual Paulista. 2007: 75. 
SOARES, M. G. M.; COSTA, E. L.; SIQUEIRA-SOUZA, F. K.; ANJOS, H. D. B. DOS; YAMAMOTO, K. C.; FREITAS, C. E. C. Peixes de lagos do Médio Rio Solimões. Rev. Manaus: Instituto Ipiatam, 2. ed., 160 p. 2008.

TAVARES-DIAS, M.; FRASCÁ-SCORVO, C. M. D.; CAMPOS-FILHO, E.; MORAES, F. R. Características hematológicas de teleósteos brasileiros. Iv. Parâmetros eritroleucométricos, trombométricos e glicemia do matrinxã (brycon cephalus günther, 1869) (osteichthyes: characidae). ARS VETERINARIA, 1999; 15(3): 149-153.

TORTOLERO, S. A. R.; SOARES, M. C. F.; MERA, P. A. S.; MONTEIRO, J. M. F. Efeito da densidade de estocagem no crescimento do matrinxã, Brycon amazonicus (spix \& agassiz, 1829) em gaiolas de pequeno volume. Rev. Bras. Eng. Pesca, 2010; 5(1): 81-92.

URBINATI, E. C.; VASQUES. L. H.; SENHORINI, J. A.; GONÇALVES, F. D. Early development of matrinxã, Brycon cephalus (Teleost, Characidae), after maternal triiodothyronine injection and egg exposure. Aquaculture, 2005.

VAL, A. L., HONCZARIK, A. Criando Peixes na Amazônia. Amazonas: INPA, p. 160. 1995.

VALBUENA, M.; VELASCO-SANTAMARÍA, Y. M.; CRUZ-CASALLAS, P. E. Efecto del peso corporal sobre el consumo de oxígeno en yamú (Brycon amazonicus Spix \& Agassiz 1829): reporte preliminar. Rev. Col. Cienc. Pec., 2006; 19(2).

ZANIBONI FILHO, E. Biologia da reprodução do matrinxã, Brycon cephalus (GÜNTHER, 1869) (TELEOSTEI: CHARACIDAE). Dissertação. Instituto Nacional de Pesquisas da Amazônia. 1985: 134.

ZANIBONI-FILHO, E.; RESENDE, E. K. Anatomia de gônadas, escala de maturidade e tipo de desova do matrinxã, Brycon cephalus (Gunther, 1869) (Teleostei: Charadae). R. Bras. Biol., $1988 ; 48(4)$ : 883-884.

ZANIBONI FILHO, E.; REYNALTE-TATAJE, D.; WEINGARTNER, M. Potencialidad del género Brycon en la piscicultura brasileña. Rev. Col. Cienc. Pec., 2006; 19(2): 233-240.

ZANUZZO, F. S. Uso da aloe vera L. no manejo de matrinxã (Brycon amazonicus). Dissertação. Universidade do Estadual Paulista. 2010: 81.

ZEINAD, A. K. Peixes do Brasil - Água Doce, Matrinxã. 200. Pesca e Companhia, 2011. 